\title{
"Resilience of Bruneian economy amidst Covid-19 based on the United Nations Disaster Risk Reduction (UNDRR) framework"
}

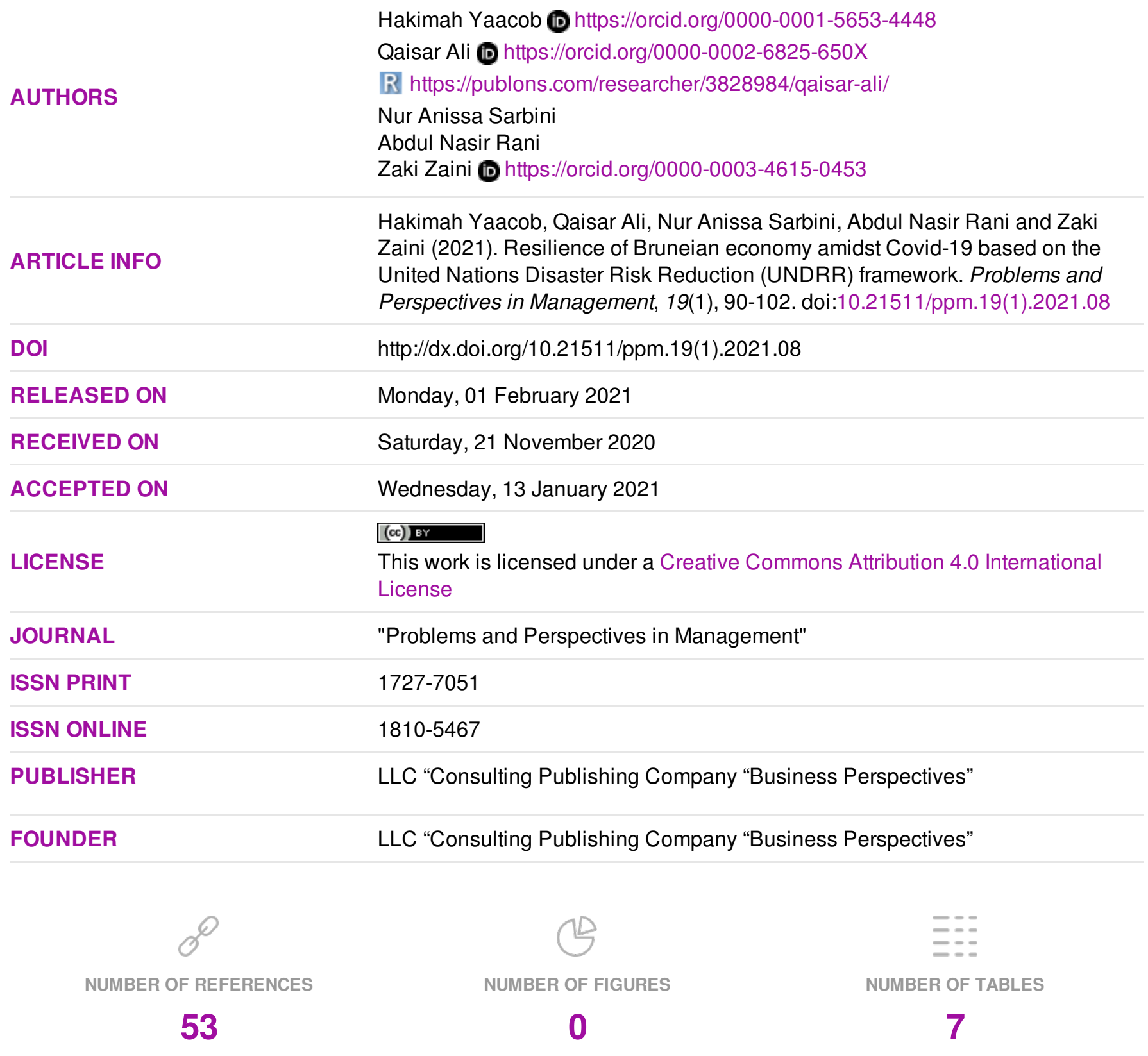

(c) The author(s) 2021. This publication is an open access article. 


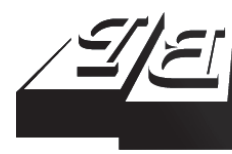

\section{BUSINESS PERSPECTIVES}

LLC "CPC "Business Perspectives" Hryhorii Skovoroda lane, 10, Sumy, 40022, Ukraine www.businessperspectives.org
Received on: $21^{\text {st }}$ of November, 2020 Accepted on: $13^{\text {th }}$ of January, 2021 Published on: $1^{\text {st }}$ of February, 2021

(๑) Hakimah Yaacob, Qaisar Ali, Nur Anissa Sarbini, Abdul Nasir Rani, Zaki Zaini, 2021

Hakimah Yaacob, Ph.D., Faculty of Islamic Economics and Finance, Sultan Sharif Ali Islamic University, Brunei Darussalam.

Qaisar Ali, Ph.D., Department of Islamic Banking and Finance, Faculty of Islamic Economics and Finance, Sultan Sharif Ali Islamic University, Brunei Darussalam. (Corresponding author)

Nur Anissa Sarbini, MA, Faculty of Islamic Economics and Finance, Sultan Sharif Ali Islamic University, Brunei Darussalam.

Abdul Nasir Rani, Ph.D., Faculty of Islamic Economics and Finance, Sultan Sharif Ali Islamic University, Brunei Darussalam.

Zaki Zaini, Ph.D., Faculty of Islamic Economics and Finance, Sultan Sharif Ali Islamic University, Brunei Darussalam.
Hakimah Yaacob (Brunei Darussalam), Qaisar Ali (Brunei Darussalam), Nur Anissa Sarbini (Brunei Darussalam), Abdul Nasir Rani (Brunei Darussalam), Zaki Zaini (Brunei Darussalam)

\section{RESILIENCE OF BRUNEIAN ECONOMY AMIDST COVID-19 BASED ON THE UNITED NATIONS DISASTER RISK REDUCTION (UNDRR) FRAMEWORK}

\begin{abstract}
The outbreak of Covid-19 is the second most devastating event over a century. The pandemic, alongside deep health crises, has ushered the largest economic shocks, which require governments' attention to ameliorate to avoid an economic downturn. The aim of this study is to measure the economic impacts of Covid-19 in Brunei by estimating the exposure, vulnerability, and resilience of the economy. This study deployed the United Nations Disaster Risk Reduction framework to examine the economic impact empirically. The data related to variables of gross domestic product, oil prices, international merchandise trade, tourism, unemployment, consumer price index, money supply, and national accounts were collected from September 2019 to July 2020 and analyzed through the fixed effects panel regression technique. The findings show that the news of the Covid-19 outbreak has exposed the weaknesses in energy sectors by having a significant negative impact. Additionally, analysis discloses that the energy and tourism sectors are vulnerable to the shocks of Covid-19. During the peak of the pandemic outbreak, unemployment in Brunei has also escalated. Additionally, the energy and tourism sectors are less resilient to pandemic shocks. The findings indicated that the consumer price index has significantly escalated during the economic recovery process. The findings elucidate that the overall GDP growth rate, international merchandise trade, and the financial sector continue exhibiting better performance amid Covid-19. The findings of this study contribute to developing policy implications for the emerging economies concerned with the economic recovery process during the pandemic.
\end{abstract}

\section{Keywords}

Covid-19, pandemic, economic shocks, Brunei, economic recovery

\section{JEL Classification E27, P44, H11}

\section{INTRODUCTION}

The case of respiratory infection caused by the novel Coronavirus (Covid-19) was first reported in Wuhan (China) on 31 December 2019, and the World Health Organization declared it a global pandemic on 11 March 2020 (WHO, 2020a). The number of new cases is escalating, and scientists have warned that the world is yet to suffer from the worse (WHO, 2020b). As of 27 July 2020, there are more than 16.19 million confirmed cases of Covid-19 and 647,846 deaths in the world (WHO, 2020b). The American region is anticipated to be the next epicenter of Covid-19 with more than 4,232,979 confirmed cases and 146,927 deaths, and many states decided to continue lockdown (WHO, 2020c). Covid-19 continues to surge globally at an alarming rate and burn economic activities to nearly a standstill as countries decided to reimpose tight safety measures to halt its spread (The World Bank, 2020a). The pandemic has disrupted economic activities at such an unprecedented pace that everyday life patterns are overturned, and econ- 
omists claim that the world has already entered into a recession (Financial Times, 2020). The emergence of Covid-19 is referred to as a black swan event as it has stifled the global economy particularly, it arrived when the global economy was already showing signs of a slowdown (IMF, 2020a). Many countries have started to ease lockdowns in phases to reopen economies and societies; however, large-scale investment in personal protective equipment (PPE), Covid-19 testing, contact tracing, cleaning, and hygiene products are essential yet challenging to execute (WHO, 2020d).

The outbreak of Covid-19 has left the global economy reeling. The Economist's (2020) article 'Not quite all there' predicted that the $90 \%$ damages to the global economy due to the ongoing pandemic would be hard to reverse. These economic damages are so devastating that the global economy shrank by 1.3\%, only within the first quarter of 2020 (The Economist, 2020), and the World Bank's (2020a) 'Global Economic Prospects' predicted the contraction of global GDP by $5.2 \%$ in 2020 . A sequential review of the economic situation worldwide reveals that global stock markets are showing the lowest downtrend as the Dow Jones Industrial Average (DJIA) dropped 13.2\%, FTSE declined 19.3\%, and Nikkei dropped $5.2 \%$ since the start of the outbreak (Bloomberg, 2020). Unemployment is rising due to businesses closure and escalating fear among people to be infected at work, which will end the expansion of advanced economies like the United States, Italy, France, Canada, United Kingdom, Germany, and Japan (IMF, 2020b). Many countries recorded a decline in GDP growth as low as $-60 \%$ to $-15 \%$, and per capita income will contract in developed countries, which will spill-over to the emerging and developing economies (The World Bank, 2020). The airlines significantly reduced their flights due to lack of demand and travel restrictions, which has pushed the tourism industry to the brink of crises (UNWTO, 2020). Lastly, the tumbling oil and gas industry due to steep crude oil prices and escalating geopolitical tension between Saudi Arabia and Russia has seriously affected the GDP growth of the countries that substantially rely on the revenue from oil and gas resources $(\mathrm{Ng}, 2020)$.

IMF's Economic Outlook released in April projected the contraction of the Asian economy by 1.6\%, which is a very rare case scenario for this region (IMF, 2020c). The projections related to Pacific Asia are relatively optimistic, although ongoing pandemic East and Pacific Asia's per capita income is expected to increase by $0.5 \%$, and Brunei has the second-highest per capita income among the countries located in East Asia (The World Bank, 2020). Pertaining to these optimistic projections, it is forecasted that Brunei's GDP growth will reach US $\$ 14.79$ billion by 2024, and the real GDP will increase by $2.12 \%$ (Statista, 2020).

The economic crises unleashed by the Covid-19 outbreak have equally affected high- and low-income countries, and a recent report by UNIDO (2020) concluded that the economic crises are not correlated with health crises. A recent study by Noy et al. (2020) found that a low impact of Covid-19 related to the number of cases and deaths does not necessarily mean a low economic impact. Similarly, a recent report of the African Development Bank (2020) projected the contraction of African countries by 1.7\% in 2020, although many regions are comparatively less affected by the pandemic. Even minor public health events can pose serious effects to the firms located in lower-income countries due to their weak capability to respond and poor socioeconomic conditions. Many countries face indirect consequences due to disruptions in the value chain and globally low demand for goods as the widespread recession looms (UNIDO, 2020).

This study has three discrete contributions in literature; first, it contributes to the ongoing research on Covid-19 impacts on economies of high-income countries by analyzing the response and strategies of Brunei Darussalam to contain the spread of the virus. Second, it contributes to estimating the actual direct impact on the economy of the country with the second-highest per capita income in Asia, which will help other East Asian countries benchmark their response to the current pandemic. Third, it contributes to mapping the indirect effects on the economy despite the significantly low spread of Covid-19, analyzing whether globally affected countries have a spill-over effect on Brunei's economy. 
The remaining paper is organized as follows: section one discusses the current situation of Covid-19, Brunei's response to the pandemic, and the empirical review of the literature related to the impacts of the pandemic on the economy. Section two describes the research methodology, and section three outlines the major findings and discussion. The last section concludes this paper.

\section{LITERATURE REVIEW}

\subsection{Current situation of Covid-19 in Brunei}

The first case of Covid-19 in Brunei was detected on 9 March 2020 in a 53 old male who returned from Malaysia together with his three friends (Ministry of Health Brunei, 2020a). The patient was held, treated, and went for initial verification in line with guidance from the World Health Organization (WHO). The Ministry of Health immediately responded with high vigilance and started contact tracing to control the spread of infection due to rising concerns of the pandemic in the ASEAN region. Brunei established a National Isolation Centre in the Tutong district to treat infected patients. Brunei did not impose chaotic lockdowns like other ASEAN countries as the situation was relatively under control, and the officials from the Ministry of Health Brunei have been transparent and avoided suppressing or hide information related to the current situation (The Asean Post, 2020). As of 13 July 2020, there were 141 positive Covid-19 cases, 3 deaths, 138 patients were recovered, and no active cases in Brunei (Ministry of Health Brunei, 2020b).

\subsection{Brunei's response to Covid-19}

Brunei is one of the few countries in the world that has successfully flattened the Covid-19 curve and has controlled its spread through its outstanding health care system and generous support from the government. All the infected patients were tested and treated freely at the National Isolation Centre, and the government established different isolation centers throughout the country. As soon as the first case of Covid-19 was reported in Brunei, the government immediately imposed a travel ban, prohibited mas public gatherings, closed mosques, restaurants (dining in) schools, gyms, and parks. Once the situation was under control, the policymakers suggested partially lift the restrictions; however, the public is encouraged to practice so- cial distancing in public places and use BruHealth App to facilitate the Ministry of Health to keep the contact tracing. Other initiatives include the early opening of the Temburong bridge to facilitate the residents of this district working in the capital Bandar Seri Begawan. The government and the banks in Brunei have mutually agreed to defer the loan payments for the industries in tourism, hospitality, events management, and food and beverage for six months (KPMG, 2020). The private sector employees were allowed to take a paid sick leave for one month, and the government announced to contribute $25 \%$ to the salaries of private-sector employees for three months to alleviate the financial burden on hard-hit sectors (The Asean Post, 2020). The Ministry of Finance and Economy (MOFE) launched a virtual platform to gather the Bruneian community to help affected micro, small, and medium enterprises (MSMEs). Through this platform, these MSMEs can sell their goods and services through a virtual platform, and the public can buy their products through digital payments (MOFE, 2020).

\subsection{Covid-19 impact on Brunei economy}

Over the past 300 years, the world has suffered from 10 major pandemics of stronger and lesser magnitude, and Potter (2001) has warned to rule out the danger of another medical disaster. During the $20^{\text {th }}$ century, the world was hit by three major pandemics; Spanish influenza in 1918, Asian influenza in 1957, and the Hong Kong influenza in 1968, which killed nearly 30 to 60 million people (Kilbourne, 2005). The actual mortality and morbidity (people who are infected) rate from these pandemics remains unknown by the historians. However, the ongoing health crises are described as the worst of all (Ferguson et al., 2020) due to the absence of pharmaceutical interventions, and the authors have labeled it as the second most devastating event in over a century (Jorda et al., 2020). The catastrophic events such as epidemics and terrorist attacks are anticipated as a black swan as it results 
in shock, fear, and panic among international investors and triggers sharp panic-selling response (Burch et al., 2016). Even though past studies have attempted to quantify pandemics; impact on economies, the researchers have failed to draw a firm conclusion concerning the long-term impact of pandemics on economies (Jonung \& Roeger, 2006).

The past studies concluded that population health, which is usually measured by life expectancy, infant and maternal mortality, has a positive correlation with economic welfare and growth (Cuddington \& Hancock, 1994; Robalino \& Voetberg, 2002; WHO Commission on Macroeconomics and Health, 2001; Haacker, 2004). Infectious disease poses direct and indirect impacts on the economy through different channels. The conventional approach uses information on mortality rate and morbidity rate to calculate future income loss due to death and disability. The additional costs associated with the disease are the time and income loss, medical expenses, and support services used to recover from the infection. However, this approach is not applicable in the case of epidemic diseases such as HIV, SARS, and pandemic influenza. The experience from previous diseases can be used as a benchmark to sketch Covid-19 implications.

The direct cost of Covid-19 was the fear among people, which posed an unprecedented challenge to the global markets and the prices of equities fell sharply from previously overstretched level. The credit market skyrocketed especially, risky segments such as high-yield bonds, leveraged loans, private debt essentially halted issuing. The oil prices plummeted due to the decline in global demand and the failure of OPEC+ countries to reach an agreement to cut output (IMF, 2020d). Similarly, Haacker (2004) found that infectious diseases such as HIV/AIDS pose a serious threat to household income, businesses, and government as they are forced to adopt alternative decisions related to labor supply, efficiency, and staff training. In the context of Brunei, Covid-19 has forced MSMEs to shift their business model to an online platform for the survival of businesses (MOFE, 2020). The Bruneian government introduced a stimulus package of BND 450 million to support the financial sector and MSMEs in the private sector, which focuses on the welfare of the Bruneian community and cushion local businesses (KPMG, 2020).
An empirical review of the literature reveals that epidemic diseases such as SARS significantly affect the economies through changes in consumption patterns of goods and services, additional operating costs, and re-evaluation of risks in a country. Often, countries with weak response strategies are susceptible to exposure to disease transmission and indirectly affected by the infection despite relatively low deaths and infection rates (Lee \& Mckibbin, 2003; Chou \& Kou, 2004; Hai \& Zhao, 2004). The case under investigation in this paper has a similar scenario: low infection and death rate; however, the global cost of Covid-19 is significantly high. Therefore, it is anticipated that the Bruneian economy may remain under pressure due to spill-over effects from the plunging global economy.

The argument discussed above can be justified by analyzing the Autoriti Monetari Brunei Darussalam (AMBD) warning regarding the rise of inflation rate amidst Covid-19, whereas the country has an exceptionally low spread rate (The Scoop, 2020). Furthermore, AMBD has projected a rise in financial stability risk, credit risk, and offshore investment risk on the banks in Brunei. Asian Development Bank (ADB) highlighted the uncertainties associated with Covid-19 by predicting that the pandemic outbreak can contract Brunei's GDP by $0.086 \%$ due to a decline in the revenue of the tourism sector (The Star, 2020).

There is a dearth of studies on the economic impacts of pandemics, especially related to Covid- 19 . Bloom et al. (2005) used the Oxford economic forecasting model to analyze the impact on GDP due to the influenza pandemic and found that the outbreak had resulted in a loss of $0.6 \%$ loss of global GDP. A study conducted by the US Congressional Budget Office (2005) found that the high fatality rate had contracted US GDP relatively more than the low fatality rate. Another study by Sidorenko and Mckibbin (2006) found that different circumstances such as 'mild' (similar to Hong Kong flu), 'moderate' (similar to Asian flu), 'severe' (similar to Spanish flu with low fatality rate), and 'ultra' (similar to Spanish flu with high fatality rate) cost global economy approximately US\$ 4.4 trillion. There is no significant study in the literature that had thoroughly investigated the economic impacts of Covid-19, except Mckibbin and Fernando (2020), 
which was conducted when the outbreak was not fully spread worldwide. Since the Covid-19 outbreak has affected about 217 countries, it will be interesting to estimate the economic effects of this pandemic, particularly in Brunei, which has the second-highest GDP among ASEAN countries.

\section{METHODS}

\subsection{Data collection}

Considering the time covered during the entire process of the outbreak in this study, it is unlikely that this study at this stage of the pandemic will accurately predict the actual impact on Brunei's economy. The selected time is ideal for identifying the economic performance of different sectors and institutions before the start of the virus outbreak, which occurred at the end of December 2019. The second phase covers the period from the start of January 2020 till the implication of lockdown and curfews by the end of March 2020. The third phase covers the period from the end of April 2020 to 15 July 2020. The data were collected from the reports and web portals of different government departments in Brunei, such as the Department of Economic Planning and Statistics (DEPS), Ministry of Health $(\mathrm{MOH})$, Ministry of Primary Resources and Tourism (MPRT), and Autoriti Monetari Brunei Darussalam (AMBD) from 1 September 2019 to 1 July 2020.

\subsection{Measurement variables}

The key assumptions used in the simulation model to analyze the magnitude of economic shocks in Brunei resulted due to Covid-19 are reported in Table 1.

Table 1. Estimation of the variables used in this study

\begin{tabular}{|c|c|c|c|}
\hline Variables & Description & $\begin{array}{l}\text { Expected } \\
\text { impact }\end{array}$ & Source \\
\hline $\begin{array}{l}\text { Gross domestic } \\
\text { product }(G D P) \text { growth }\end{array}$ & $\begin{array}{l}\text { The variable of GDP growth rate is expected to estimate the impact on the real } \\
\text { economy of Brunei. Despite the contraction in global GDP growth rate as low as } 4.2 \% \text {, } \\
\text { Brunei GDP grew by } 2.4 \% \text { in the first quarter of } 2020\end{array}$ & $(+)$ & DEPS \\
\hline Oil prices $(O P)$ & $\begin{array}{l}\text { The plummeted oil prices during the Covid-19 outbreak due to lack of demand and } \\
\text { supply issues, and the failure of an agreement between OPEC and Russia has jolted the } \\
\text { energy sector. The energy sector contributes } 97 \% \text { to the economy of Brunei; hence, it } \\
\text { is interpreted that this variable will depict the true economic impact of the pandemic } \\
\text { outbreak in Brunei }\end{array}$ & $(-)$ & DEPS \\
\hline $\begin{array}{l}\text { International } \\
\text { merchandise trade } \\
(\text { IMT) }\end{array}$ & $\begin{array}{l}\text { This variable will estimate the exposure and vulnerability of Brunei's export-dependent } \\
\text { economy, especially in the face of a decline in global demand due to stringent measures } \\
\text { imposed by hard-hit Covid-19 countries }\end{array}$ & $(-)$ & DEPS \\
\hline Tourism $^{\mathrm{TM}}$ & $\begin{array}{l}\text { This simulation variable will estimate the impact on the tourism industry especially, } \\
\text { suspension of flights and lockdown measures to contain the spread of infection have } \\
\text { seized the flow of tourist worldwide. Hence, a cautious projection is that Covid-19 will } \\
\text { be a worst-case scenario for this industry }\end{array}$ & $(-)$ & MPRT \\
\hline $\begin{array}{l}\text { Unemployment rate } \\
(U R)\end{array}$ & $\begin{array}{l}\text { Globally, unemployment is rising due to the closure of businesses, employers have } \\
\text { furloughed workers, and fear among workers to get infected at work. It is anticipated } \\
\text { that the pandemic might have accelerated unemployment in Brunei }\end{array}$ & $(-)$ & DEPS \\
\hline $\begin{array}{l}\text { Consumer price index } \\
(C P I)\end{array}$ & $\begin{array}{l}\text { The governments have introduced stimulus packages to combat Covid-19; however, } \\
\text { it is anticipated that the price of goods will increase firstly due to global supply chain } \\
\text { issues; secondly, the panic buying response among the public will escalate the demand } \\
\text { for goods. Brunei is expected to experience a rise in consumer price index due to high } \\
\text { dependence on the goods imported from other countries }\end{array}$ & $(+)$ & DEPS \\
\hline Money supply (MS) & $\begin{array}{l}\text { The contraction of GDP growth may force the governments to cut their expenditures, } \\
\text { which will result in a shortage of money supply. Despite the provision of the stimulus } \\
\text { package by the governments, it is projected that the pandemic will affect the money } \\
\text { supply in the long run }\end{array}$ & $(-)$ & AMBD \\
\hline $\begin{array}{l}\text { National accounts } \\
\text { (NA) }\end{array}$ & $\begin{array}{l}\text { Since Brunei has reported a positive growth rate hence, it is projected that the national } \\
\text { accounts balance has increased, and Covid-19 will not have a significant impact as } \\
\text { Brunei has successfully contained the spread of infection }\end{array}$ & Neutral & AMBD \\
\hline
\end{tabular}




\subsection{Model description}

The impact of Covid-19 on Brunei's economy is calculated using simple regression analysis, which is as follows:

$$
\begin{aligned}
& \text { Risk }_{g}=\alpha+\beta_{1} \text { Exposure }_{g}+ \\
& +\beta_{2} \text { Vulnerability }_{g}+\beta_{3} \text { Resilience }_{g},
\end{aligned}
$$

where as risk represents the outbreak of Covid-19, $g$ is a magnitude, $\alpha$ and $\beta$ are the regression coefficients.

For the purpose of this study, the above model is simulated as follows:

$$
\begin{aligned}
& \text { Risk }_{g}=\alpha+\beta_{1}(G D P G+O P+I M T+T M+ \\
& +U R+C P I+M S+N A) \text { Exposure }_{g}+ \\
& +\beta_{2}(G D P G+O P+I M T+T M+ \\
& +U R+C P I+M S+N A) V u \ln \text { erability }_{g}+ \\
& +\beta_{3}(G D P G+O P+I M T+T M+ \\
& +U R+C P I+M S+N A) \text { Re } \text { silience }_{g} .
\end{aligned}
$$

where as risk represents the outbreak of Covid-19, $g$ is a magnitude, $\alpha$ and $\beta$ are the regression coefficients, GDPG, OP, IMT, TM, $U R, C P I, M S$, and NA represent the growth rate of gross domestic product, oil prices, international merchandise trade, tourism, unemployment rate, consumer price index, money supply, and national accounts, respectively, in the equation given earlier.

The time events used during the data collection will test the exposure, vulnerability, and resilience of the Bruneian economy during the Covid-19. The time event between 1 September 2019 and 9 January 2020, which is the start of the Covid-19 pandemic, represents the exposure to the economic shocks in Brunei. The second time event from 10 January 2020 to 11 March 2020 represents the vulnerability of Brunei's economy to Covid-19 shocks. The third time event covers the period from 27 April 2020 to 15 July 2020, and it represents the resilience in Brunei's economy from Covid-19 shocks.

\section{RESULTS AND DISCUSSION}

\subsection{Exposure to economic shocks amidst Covid-19}

Firstly the analyses focus on Brunei's exposure to economic shocks during Covid-19. To estimate this, the time event between 1 September to 9 January was considered as this duration covers the time when the first case of the Covid-19 outbreak was reported in China, which will directly analyze whether the economic system of Brunei experiences significant shocks due to the news of the outbreak. To estimate the exposure, mean, median, and standard deviation of the simulation model variables were estimated. Additionally, $t$-test was performed to analyze the significance of an event's economic impact, which is essential to calculate the economic indicator's deviation from the average (Chen \& Siems, 2004). The results of mean, median, standard deviation, and $t$-test are reported in Table 2.

Table 2. Results of mean, median, and standard deviation

\begin{tabular}{l|c:c:c:c}
\hline \multicolumn{1}{c}{ Indicator } & Mean & Median & SD & t-statistics \\
\hline GDP & 2.122 & 2.148 & 0.016 & 0.36 \\
\hline OP & 1.980 & 1.871 & 0.019 & $-0.59^{*}$ \\
\hline IMT & 1.032 & 1.043 & 0.007 & 0.23 \\
\hdashline TM & 1.067 & 1.047 & 0.230 & 0.67 \\
UR & 1.367 & 1.287 & 0.152 & 0.45 \\
CPI & 2.376 & 2.181 & 0.690 & 0.13 \\
MS & 1.832 & 1.920 & 0.723 & 0.89 \\
NA & 1.478 & 1.460 & 0.341 & 0.88 \\
\hline
\end{tabular}

Note: $*$ represents significance at the $5 \%$ level, and ${ }^{* *}$ represents significance at the $1 \%$ level.

The results in Table 2 indicate that mean, median, and standard deviation have a positive value, which indicates that economic indicators such as trade (GDP growth rate), real economy (oil prices, international trade merchandise, tourism, unemployment rate, consumer price index) and finance sector (money supply and national accounts) show regular performance. Moreover, $t$-statistics have an insignificant positive value (except oil prices), which indicates that the economic indicators do not deviate from their average performance despite the initial news of the pandemic outbreak. The oil prices indicator shows a negative and significant (5\%) value, which can be cautiously inter- 
Table 3. Results of panel regression analysis (exposure scenario)

\begin{tabular}{|c|c|c|c|c|c|}
\hline Indicator & Coefficient & S. E & t-statistics & Prob. & Sig. \\
\hline GDP & 2.0349872 & 0.0756934 & 3.683400 & 0.001 & \\
\hline OP & 1.0986754 & 0.0234633 & -3.547802 & 0.000 & $* * *$ \\
\hline IMT & 1.7807653 & 0.0187450 & 2.743019 & 0.004 & \\
\hline TM & 1.0459824 & 0.0396775 & 2.780780 & 0.001 & $* *$ \\
\hline UR & 1.0659852 & 0.0673461 & 3.875230 & 0.004 & \\
\hline $\mathrm{CPI}$ & 1.0785683 & 0.0103478 & 2.532987 & 0.002 & \\
\hline MS & 2.0757923 & 0.0767340 & 1.329856 & 0.000 & \\
\hline \multirow[t]{9}{*}{ NA } & 2.04671226 & 0.0240238 & 1.873415 & 0.001 & \\
\hline & & \multicolumn{4}{|c|}{ Effects specification } \\
\hline & & $R^{2}$ & 0.804570 & Mean dependent var. & 0.830 \\
\hline & & Adjusted $R^{2}$ & 0.774501 & S.D dependent var. & -0.3482 \\
\hline & & S. E of regression & 0.128903 & Akaike info criterion & -0.43209 \\
\hline & & Sum square residual & 0.468902 & Schwarz criterion & -1.42376 \\
\hline & & Long likelihood & 212.3012 & Hannan-Quinn criteria & -1.73209 \\
\hline & & F-statistics & 22.2374 & \multirow{2}{*}{ Durbin-Watson stat } & \multirow{2}{*}{1.340986} \\
\hline & & Probability & 0.00001 & & \\
\hline
\end{tabular}

Note: $* * *$ represents significance at $1 \%, * *$ at $5 \%$, and $*$ at $10 \%$, respectively.

preted as the market volatility, plummeting crude oil prices, and exacerbating supply in the global oil and gas market during the last quarter of 2019 (Mckinsey, 2019).

To further confirm whether the Covid-19 news outbreak has exposed Brunei's economy to experience economic shocks, panel regression analysis was used. The panel data technique is useful in providing explanatory data for cross-sectional information. Moreover, it is a suitable method as it successfully explains the variance in a variable over a specific time duration, which will help record dynamic adjustment (Ali et al., 2018). The fixed effects panel regression method was preferred over the random effect as the latter technique requires cross-sections to be greater than coefficients. The results of the regression analysis are reported in Table 3.

The results of the panel regression analysis (Table 3 ) indicate that the selected model is suitable to estimate the exposure to economic shocks of Covid-19 as the values of $R^{2}(80.45 \%)$ and adjusted $R^{2}(77.45 \%)$ are greater than the threshold value of $60 \%$. Now, moving to the results of coefficients, $t$-statistics, and significance, it is clear that gross domestic product (GDP), international merchandise trade (IMT), unemployment rate (UR), consumer price index (CPI), money supply (MS), and national accounts (NA) have the positive and insignificant values, which indicates that these var- iables are performing normal and are not exposed to Covid-19 shocks. Whereas coefficients, $t$-values, and significance results of oil prices (OP) and tourism (TM) have negative values, which are significant at $1 \%$ and $5 \%$ level. Indeed, these two sectors are significantly exposed to the shocks of Covid-19 due to the decline in global demand for oil, and many countries issued a travel warning and imposed bans to control the spread of infection.

\subsection{Vulnerability to economic shocks amid Covid-19}

To analyze the Brunei economy's vulnerability to Covid-19 shocks again mean, median, standard deviations, and $t$-statistics of the economic indicators during the second phase were estimated. The results are reported in Table 4.

Table 4. Mean, median, standard deviation, and $t$-tests results

\begin{tabular}{l|c:c:c:c}
\hline \multicolumn{1}{c}{ Indicator } & Mean & Median & SD & t-statistics \\
\hline GDP & 1.834 & 2.012 & 0.017 & 0.56 \\
\hdashline OP & -1.324 & -1.497 & -0.230 & $-0.46^{* *}$ \\
\hdashline IMT & 0.934 & 0.834 & 0.102 & 0.12 \\
\hdashline TM & -0.645 & -0.567 & -0.034 & $0.32^{*}$ \\
UR & -2.340 & -2.022 & -0.032 & $-0.75^{* *}$ \\
\hline CPI & 1.210 & 1.343 & 0.002 & 0.22 \\
MS & 1.909 & 1.888 & 0.045 & 0.18 \\
NA & 1.450 & 1.501 & 0.021 & 0.09 \\
\hline
\end{tabular}

Note: * represents significance at the $5 \%$ level and ** represents significance at the $1 \%$ level. 
The results in Table 4 show that the economic indicators such as the energy sector (oil prices), tourism, and labor (unemployment rate) have a negative mean, representing that these three sectors are weak and vulnerable to the shocks of Covid-19. While gross domestic product, international trade merchandise, consumer price index, money supply, and national accounts have positive and insignificant values, it is inferred that these economic sectors can absorb the shocks of Covid-19. Additionally, $t$-test values show that oil prices, tourism, and unemployment rate have negative values, significant at $1 \%, 5 \%$, and $1 \%$ level. This finding affirms the dire need for alternative methods to diversify Brunei's economy and minimize its dependence on the revenue from oil and gas and tourism. Covid-19 is a straw that broke the camel's back, especially when the oil-dependent economies face dual shocks of human and economic loss (Arezki et al., 2020).

The panel regression analysis was also performed to explore the vulnerability of Brunei's economy to the possible shocks of Covid-19. Table 5 reports the results of panel regression analysis.

The results of $R^{2}$ and adjusted $R^{2}$ in Table 5 verify that the economic variables selected in this scenario match the criteria of model fitness as the values of $R^{2}(78.23 \%)$ and adjusted $R^{2}(72.47 \%)$ are greater than its threshold criteria of $60 \%$. The values of oil price, tourism, and unemployment rate are negative and significant at $1 \%, 5 \%$, and $10 \%$ level, respectively, which indicates that these three variables are significantly vulnerable to the shocks of Covid-19. In contrast, other variables such as GDP, international trade merchandise, consumer price index, money supply, and national accounts have positive and insignificant values, which indicates that these variables are not vulnerable to the economic shocks poised by Covid- 19 .

\subsection{Resilience to economic shocks amid Covid-19}

The resilience of the Bruneian economy to the possible shocks of Covid-19 is measured by performing similar tests. The spread of infection seems contained in Brunei at this stage; however, there are countries in the world, such as Africa and Fiji, despite the low spread of virus economy of these countries contracted due to spill-over effects and lack of resilience in the economy (Noy et al., 2020). This stage of analysis is essential to develop the implications for economic recovery in case of a bad economic situation in Brunei. The mean, median, standard deviation, and $t$-statistics were estimated to test the resilience of Brunei's economy. The results of these tests are reported in Table 6.

Table 5. Panel regression analysis (vulnerability scenario)

\begin{tabular}{|c|c|c|c|c|c|}
\hline Indicator & Coefficient & S. E & $t$-statistics & Prob. & Sig. \\
\hline GDP & 1.8456023 & 0.0123403 & 2.123456 & 0.002 & \\
\hline OP & 0.9023457 & 0.0332349 & -1.094560 & 0.001 & $* * *$ \\
\hline $\mathrm{IMT}$ & 1.9023494 & 0.0458902 & 2.347593 & 0.002 & \\
\hline TM & 0.9334504 & 0.0389032 & -1.083422 & 0.000 & $* *$ \\
\hline UR & 2.0323457 & 0.0348903 & -3.771257 & 0.001 & $*$ \\
\hline CPI & 2.0324567 & 0.0173489 & 3.578880 & 0.003 & \\
\hline MS & 1.9023456 & 0.0534789 & 2.440364 & 0.002 & \\
\hline \multirow[t]{9}{*}{ NA } & 2.2134550 & 0.0012345 & 3.892120 & 0.002 & \\
\hline & & \multicolumn{4}{|c|}{ Effects specification } \\
\hline & & $R^{2}$ & 0.782320 & Mean dependent var. & 0.120 \\
\hline & & Adjusted $R^{2}$ & 0.724758 & S.D dependent var. & -0.4021 \\
\hline & & S. E of regression & 0.234501 & Akaike info criterion & -0.65302 \\
\hline & & Sum square residual & 0.5590 & Schwarz criterion & -2.17345 \\
\hline & & Long likelihood & 107.8021 & Hannan-Quinn criteria & -2.43201 \\
\hline & & F-statistics & 17.3702 & \multirow{2}{*}{ Durbin-Watson stat } & \multirow{2}{*}{1.532892} \\
\hline & & Probability & 0.00000 & & \\
\hline
\end{tabular}

Note: $* * *$ represents significance at $1 \%, * * 5 \%$, and $* 10 \%$, respectively. 
Table 6. Results of mean, median, and $t$-test

\begin{tabular}{|c|c|c|c|c|}
\hline Indicator & Mean & Median & SD & t-statistics \\
\hline GDP & 2.254 & 2.215 & 0.013 & 0.89 \\
\hline OP & -2.134 & -2.078 & -0.023 & $-0.64 *$ \\
\hline IMT & 1.432 & 1.395 & 0.048 & 0.48 \\
\hline TM & -0.581 & -0.567 & -0.016 & $-0.17 * *$ \\
\hline UR & 2.250 & 2.234 & 0.008 & 0.83 \\
\hline $\mathrm{CPI}$ & -2.345 & -2.226 & -0.010 & $-0.77 * *$ \\
\hline MS & 3.780 & 3.653 & 0.097 & 1.10 \\
\hline NA & 2.007 & 1.895 & 0.054 & 0.73 \\
\hline
\end{tabular}

Note: $*$ represents significance at the $5 \%$ level, and $* *$ represents significance at the $1 \%$ level.

Table 7. Results of panel regression analysis (resilience scenario)

\begin{tabular}{|c|c|c|c|c|c|}
\hline Indicator & Coefficient & S. E & t-statistics & Prob. & Sig. \\
\hline GDP & 2.4573450 & 0.0450542 & 2.234027 & 0.000 & \\
\hline OP & 2.4859495 & 0.0406438 & -2.204570 & 0.000 & $* *$ \\
\hline IMT & 2.6904568 & 0.0284532 & 2.457732 & 0.001 & \\
\hline TM & 1.4578324 & 0.0153493 & -0.930454 & 0.000 & $*$ \\
\hline UR & 1.6532400 & 0.0221456 & -1.320349 & 0.002 & \\
\hline $\mathrm{CPI}$ & 2.2045248 & 0.0643213 & -1.738432 & 0.000 & $* * *$ \\
\hline MS & 3.3274710 & 0.0732940 & 2.330488 & 0.001 & \\
\hline \multirow[t]{9}{*}{ NA } & 1.9034538 & 0.0327455 & 3.450845 & 0.001 & \\
\hline & & \multicolumn{4}{|c|}{ Effects specification } \\
\hline & & $R^{2}$ & 0.806645 & Mean dependent var. & 0.345 \\
\hline & & Adjusted $R^{2}$ & 0.786732 & S.D dependent var. & -0.4067 \\
\hline & & S. E of regression & 0.341000 & Akaike info criterion & -0.70437 \\
\hline & & Sum square residual & 0.3429 & Schwarz criterion & -3.45678 \\
\hline & & Long likelihood & 182.4036 & Hannan-Quinn criteria & -3.53209 \\
\hline & & F-statistics & 21.5320 & \multirow{2}{*}{ Durbin-Watson stat } & \multirow{2}{*}{1.7035890} \\
\hline & & Probability & 0.00001 & & \\
\hline
\end{tabular}

Note: ${ }^{* * *}$ represents significance at $1 \%, * * 5 \%$, and $* 10 \%$, respectively.

The results in Table 6 show that mean, median, and $t$-values of GDP growth rate, international merchandise trade, unemployment rate, money supply, and national accounts are positive, which confirms the resilience of these economic sectors. In contrast, the energy and tourism sector continues to underperform along with a significant rise (1\% level) in the consumer price index as their means found to have negative and significant $t$-test values.

The resilience of Brunei's economy is also tested using panel regression analysis. The results of panel regression analysis are reported in Table 7.

The results in Table 7 show that the model fitness criteria are satisfactory as the values of $R^{2}(80.66 \%)$ and adjusted $R^{2}(78.67 \%)$ is greater than the threshold value of $60 \%$. The coefficients, $t$-values, and significance values further confirm that GDP growth rate, international merchandise trade, unemployment rate, money supply, and national accounts are resilient to the shocks of Covid-19. In contrast, energy and tourism sectors are not resilient as they continue to underperform despite control of the pandemic outbreak in Brunei. The significant rise in the consumer price index is possibly due to the imbalance between demand and supply. This finding can be interpreted as an ongoing battle against Covid-19 that has resulted in a lack of demand for crude oil, and the imposition of travel restrictions by many countries has severely affected the global tourism sector. Hence, we predict that the energy sector, tourism sector, and the consumer price index are less resilient to the shocks of Covid-19 due to spill-over effects from the countries battling against the pandemic. 


\section{CONCLUSION}

This study examined the economic shocks in Brunei triggered by the Covid-19 pandemic. These shocks were estimated by analyzing the phases of a pandemic outbreak. This study deployed a popular model known as the 'United Nations Disaster Risk Reduction' (UNDRR) framework to analyze economic shocks. The collected data of the adopted variables indicates that the energy and tourism sectors, unemployment, and consumer price index are the most affected, vulnerable, and less resilient sectors of the economy.

The results in this study indicate that the energy and tourism sectors were significantly affected by the initial news of the Covid-19 outbreak. While the pandemic was at its peak in Brunei, the energy and tourism sectors continue to plunge, and unemployment escalated during this period, a typical response of Covid-19 as many SMEs in Brunei furloughed workers to cut cost and minimize the spread of infection. The resilience scenario results predicted that the energy and tourism sector continues to underperform. The consumer price index shows less resilience due to the disproportionate balance between demand and supply of goods and services. Interestingly, the GDP growth rate and international trade shows resilience and are less vulnerable to economic shocks due to their capacity to absorb the shocks of Covid-19.

This validation of the estimation model (UNDRR) in the context of economic shocks measurement ushered by Covid-19 is the main contribution of this study. This will help the governments develop the matrices to inspect the economic shocks during the transformational event such as Covid-19.

This study has various theoretical and practical implications for regulators and policymakers. First, governments need to ensure that it continues practicing the policies suggested for economic recovery by international regulatory bodies such as the World Bank and IMF. Second, the government may consider revising and introducing another stimulus package for MSMEs, which will develop capacities to cushion the Bruneian economy through economic diversification and acting as a substitute to the energy and tourism sector. Third, the government needs to develop a broad socioeconomic development plan inclusive of the sector by sector plan that will help develop an ecosystem to encourage entrepreneurship and ensure success for the businesses with a sustainable model. Lastly, policymakers and the public should strictly continue practicing precautionary measures within the societies and at the workplace so that Covid-19 remains subsided in Brunei.

\section{AUTHOR CONTRIBUTIONS}

Conceptualization: Hakimah Yaacob.

Formal analysis: Hakimah Yaacob.

Investigation: Abdul Nasir Rani.

Methodology: Nur Anissa Sarbini.

Project administration: Abdul Nasir Rani.

Resources: Nur Anissa Sarbini.

Software: Qaisar Ali.

Supervision: Zaki Zaini.

Validation: Qaisar Ali.

Visualization: Qaisar Ali, Zaki Zaini.

Writing - original draft: Nur Anissa Sarbini, Abdul Nasir Rani.

Writing - review \& editing: Hakimah Yaacob, Zaki Zaini. 


\section{REFERENCES}

1. African Development Bank. (2020). African Economic Outlook 2020. Retrieved July 10, 2020, from https://www.afdb.org/en/ news-and-events/press-releases/ post-covid-19-africas-growthstands-rebound-3-2021-africandevelopment-bank-says-africaneconomic-outlook-2020-supplement-36768

2. Ali, Q., Selamah, M., Yaacob, H., \& Gill, M. U. (2018). Impact of Macroeconomic Variables on Islamic Banks Profitability. Journal of Accounting and Applied Business Research, 1(2), 1-16. Retrieved from https://www.researchgate. net/publication/324910815_Impact_of_Macroeconomic_Variables_on_Islamic_Banks_Profitability

3. Arezki, R., Yuting, R., \& Nguyen, F. (2020). Coping with Covid-19 and oil price collapse in the Gulf Cooperation Council. World Bank Blogs. Retrieved June 22, 2020, from https://blogs.worldbank.org/ arabvoices/coping-covid-19-andoil-price-collapse-gulf-cooperation-council

4. Baqaee, D., \& Farhi, E. (2020). Supply and Demand in Disaggregated Keynesian Economies with an Application to the Covid-19 Crisis (NBER Working Paper No. 27152). Retrieved from https://www.nber. org/papers/w27152

5. Bloom, E. A., De-Wit, V., Jose, C. S., \& Jane, M. F. (2005). Potential Economic Impact of an Avian Flu Pandemic on Asia. Asian Development Bank. Retrieved July 2, 2020, from https://www. adb.org/publications/potentialeconomic-impact-avian-flu-pandemic-asia

6. Bloomberg. (2020). S\&P 500 erases June losses after record home sales: Market Wrap. Retrieved July 10, 2020, from https:// www.bloomberg.com/news/ articles/2020-06-28/asian-stocksto-decline-yen-edges-highermarkets-wrap

7. Çakmakli, C., Demiralp, S., Kalemli-Özcan, S., Yesiltas,
S., \& Yildirim, M. A. (2020). Covid-19 and Emerging Markets: An Epidemiological Multi-Sector Model for a Small Open Economy with an Application to Turkey (NBER Working Paper No. 27191). Retrieved from https://www.nber. org/papers/w27191

8. Chen, A. H., \& Siems, T. F. (2004). The Effects of Terrorism on Global Capital Markets. European Journal of Political Economy, 20(2), 349-366. https://doi.org/10.1016/j.ejpoleco.2003.12.005

9. Chou, J., \& Kuo, N. F. (2004). Potential Impacts of the SARS Outbreak on Taiwan's Economy. Asian Economic Papers, 3(1), 84-112. Retrieved from https://ideas.repec. org/a/tpr/asiaec/v3y2004i1p84-99. html

10. Congressional Budget Office. (2005) A Potential Influenza Pandemic: Possible Macroeconomic Effects and Policy Issues. CBO Washington DC. Retrieved from https://www.cbo.gov/sites/default/ files/109th-congress-2005-2006/ reports/12-08-birdflu.pdf

11. Cuddington, J. T., \& Hancock, J. D. (1994). Assessing the Impact of AIDS on the Growth Path of the Malawian Economy. Journal of Development Economics, 43(2), 363368. https://doi.org/10.1016/03043878(94)90013-2

12. Department of Economic Planning and Statistics (DEPS). (2020). National Accounts-Latest Highlights. Retrieved July 20, 2020, from http:// www.deps.gov.bn/SitePages/National\%20Accounts.aspx\#: :text=In\%20 the $\% 20$ first $\% 20$ quarter\%20 of,4.8\%20billion\%20in\%20Q4\%20 2019

13. Ferguson, N., Laydon, D., Nedjati Gilani, G., Imai, N., Ainslie, K., Baguelin, M., Bhatia, S., Boonyasiri, A., Cucunuba Perez, Z., Cuomo-Dannenburg, G., Dighe, A., Dorigatti, I., Fu, H., Gaythorpe, K., Green, W., Hamlet, A., Hinsley, W., Okell, L., Van Elsland, S., ... Ghani, A. (2020). Impact of nonpharmaceutical interventions (NPIs) to reduce Covid-19 mortality and healthcare demand. Retrieved July
10, 2020, from https://www.imperial.ac.uk/media/imperial-college/ medicine/sph/ide/gida-fellowships/ Imperial-College-COVID19-NPImodelling-16-03-2020.pdf

14. Financial Times. (2020). Pandemic is causing the biggest disruption in decades to economies across the world. Retrieved July 7, 2020, from https://www.ft.com/content/e5879009-f451-4a54-9374$03472 \mathrm{f} 2 \mathrm{c} 4085$

15. Haacker, M. (2004). The Macroeconomics of HIV/AIDS. IMF, Washington DC. Retrieved from https://www.imf.org/external/pubs/ $\mathrm{ft} /$ aids/eng/

16. Hai, W., \& Zhao, Z. (2004). The Short-Term Impact of SARS on the Chinese Economy. Asian Economic Papers, 3(1), 57-61. Retrieved from https://ideas.repec.org/a/tpr/asiaec/ v3y2004ilp57-61.html

17. Hallegatte, S. (2014). Economic Resilience: Definition and Measurement (World Bank Policy Research Working Paper 6852). Retrieved from https:// openknowledge.worldbank.org/ handle/10986/18341

18. International Monetary Fund (IMF). (2020a). IMF data mapper: Real GDP growth. Retrieved June 27, 2020, from https://www.imf. org/external/datamapper/NGDP_ RPCH@WEO/OEMDC/ADVEC/ WEOWORLD

19. International Monetary Fund (IMF). (2020b). World Economic Outlook, June 2020, A crises like no other, An uncertain recovery. Retrieved July 11, 2020, from https://www.imf.org/en/Publications/WEO/Issues/2020/06/24/ WEOUpdateJune2020

20. International Monetary Fund (IMF). (2020c). Reopening Asia: How the Right Policies Can Help Economic Recovery. Retrieved July 11, 2020, from https://blogs.imf. org/2020/06/30/reopening-asiahow-the-right-policies-can-helpeconomic-recovery/

21. International Monetary Fund (IMF). (2020d). Global Financial stability report: Markets in the time 
of Covid-19. Retrieved July 11, 2020, from https://www.imf.org/en/Publications/GFSR/Issues/2020/04/14/ global-financial-stability-reportapril-2020

22. Jorda, O., Singh, S. R., \& Taylor A. M. (2020). Long run Economic Consequences of Pandemics (Federal reserve Bank of San Francisco. Working Paper 202009). Retrieved July 7, 2020, from https://www.frbsf.org/economicresearch/files/wp2020-09.pdf

23. Kilbourne, E. D. (2006). Influenza Pandemics of the 20th Century. Emerging Infectious Diseases, 12(1).

24. KPMG. (2020). Brunei Darussalam Government and institution measures in response to Covid-19. Retrieved June 29, 2020, from https://home.kpmg/xx/en/ home/insights/2020/04/bruneidarussalam-government-andinstitution-measures-in-responseto-covid.html

25. Lars Jonung, L., \& Roeger, W. (2006). The macroeconomic effects of a pandemic in Europe A model-based assessment. Directorate-General for Economic and Financial Affairs Publications. Retrieved July 10, 2020, from https://ec.europa.eu/economy_finance/publications/pages/publication708_en.pdf

26. Lee, J., \& McKibbin, W. J. (2003). Globalization and Disease: The Case of SARS. Asian Economic Papers, 3(1), 113131. Retrieved from https:// www.mitpressjournals.org/doi/ pdf/10.1162/1535351041747932

27. Mandel, A., \& Veetil, V. (2020). The Economic Cost of COVID Lockdowns: An Out-ofEquilibrium Analysis. Economics of Disasters and Climate Change, 4, 431-451. https://doi.org/10.1007/ s41885-020-00066-Z

28. Mckibbin, W. J., \& Fernando, R. (2020). The Global Macroeconomic Impacts of Covid-19: Seven Scenarios (CAMA Working Paper 19/2020). Retrieved from https:// cama.crawford.anu.edu.au/sites/ default/files/publication/cama_ crawford_anu_edu_au/2020 03/19_2020_mckibbin_fernando_0.pdf
29. Mckinsey. (2020). Global Oil Supply and Demand Outlook. Retrieved July 13, 2020, from https://www.mckinsey.com/ solutions/energy-insights/globaloil-supply-demand-outlookto-2035/ /media/231FB01E49374 31B8BA070CC55AA572E.ashx

30. Ministry of Finance and Economy (MOFE). (2020). Initiatives in Combating the Impact of Covid-19 to Brunei Darussalam's SocioEconomy. Retrieved July 12, 2020, from https://www.mofe.gov. bn/Lists/News/NewDispForm. aspx? ID $=118$

31. Ministry of Health Brunei. (2020a). Detection of the first case of Covid-19 infection in Brunei Darussalam (Press Release-9 March 2020). Retrieved July 10, 2020, from http://www. moh.gov.bn/Shared\%20Documents/2019\%20ncov/press $\% 20$ releases/FINAL\%20Press\%20Release $\% 20$ (eng)\%20-\%20First $\% 20$ Case\%20Covid-19\%20in\%20Brunei\%20Darussalam\%20(2).pdf

32. Ministry of Health Brunei. (2020b). Press release on the current situation of the Covid-19 infection in Brunei Darussalam-13 July 2020. Retrieved July 14, 2020, from https:// healthresource-1258280810. cos.ap-singapore.myqcloud. com/67f415cc-c56a-11ea-a5917a9b1b9e2941.pdf

33. Ng, A. (2020). Three ways the corona virus could have an impact on Middle East economies. CNBC. Retrieved June 24, 2020, from https://www.cnbc. com/2020/03/12/three-ways-thecorona-virus-could-impact-themiddle-east-economies.html

34. Noy, I., \& Shields, S. (2019). The 2003 Severe Acute Respiratory Syndrome Epidemic: A Retroactive Examination of Economic Costs (Asian Development Bank Economics Working Paper Series No. 591). Retrieved from https:// www.adb.org/publications/sarsepidemic-2003-examinationeconomic-costs

35. Noy, I., Doan, N., Ferrarini, B., \& Park, D. (2020). The Economic Risk of Covid-19 in Developing countries: Where is it highest? International Development Journal Policy, 38-52. Retrieved from https://ideas.repec.org/h/cpr/ebchap/p330-02.html

36. Potter, W. (2001). A History of Influenza. Journal of Applied Microbiology, 91, 572-79. Retrieved from https://sfamjournals.onlinelibrary.wiley. com/doi/full/10.1046/j.13652672.2001.01492.x

37. Prager, F., Wei, D., \& Rose, A. (2017). Total economic consequences of an influenza outbreak in the United States. Risk Analysis, 37(1), 4-19. https:// doi.org/10.1111/risa.12625

38. Robalino, D. A., \& Voetberg, A. (2002). The Macroeconomic Impacts of AIDS in Kenya Estimating Optimal Reduction Targets for the HIV/AIDS Incidence Rate. Journal of Policy Modeling, 24(2), 195-218. https://doi.org/10.1016/S01618938(02)00097-2

39. Sidorenko, A. A., \& McKibbin W. J. (2006). Global Macroeconomic Consequences of Pandemic Influenza (81 p.). Crawford School of Public Policy. Retrieved July 3, 2020, from https://cama. crawford.anu.edu.au/pdf/working-papers/2006/262006.pdf

40. Statista. (2020). Economy Outlook: Brunei Darussalam. Retrieved July 11, 2020, from https://www.statista.com/outlook/998/181/economy/bruneidarussalam\#market-inflation

41. The Economist. (2020). The $90 \%$ economy that lockdowns will leave behind. Retrieved July 5 , 2020, from https://www.economist.com/briefing/2020/04/30/ the-90-economy-that-lockdownswill-leave-behind

42. The Scoop. (2020). Covid-19 pandemic pushes up Brunei's inflation rate-08 July 2020. Retrieved July 10, 2020, from https://thescoop.co/2020/07/08/ covid-19-pandemic-pushes-upbruneis-inflation-rate/

43. The Star. (2020). Covid-19 affects Brunei's tourism revenue, says ADB-09 March 2020. Retrieved 
July 8, 2020, from https://www. thestar.com.my/news/regional/2020/03/09/covid-19-affectsbruneis-tourism-revenue-says$\mathrm{adb}$

44. The World Bank. (2020a). The Global Economic Outlook During the Covid-19 Pandemic: A Changed World. Retrieved July 7, 2020, from https://www. worldbank.org/en/news/feature/2020/06/08/the-global-economic-outlook-during-the-covid19-pandemic-a-changed-world

45. United Nations Industrial Development Organization (UNIDO). (2020). Coronavirus: The Economic Impact. Retrieved July 11, 2020, from https://www. unido.org/stories/coronaviruseconomic-impact-10-july-2020

46. United Nations Office for Disaster Risk Reduction (UNDRR). (2017). Terminology. Retrieved July 12,
2020, from https://www.undrr.org/ terminology

47. United Nations World Tourism Organization (UNWTO). (2020). The Time has come to restart the tourism! Retrieved July 11, 2020, from https://www.unwto.org/ un-tourism-news-13-restartingtourism

48. Van der Mensbrugghe, D. (2008) The Environmental Impact and Sustainability Applied General Equilibrium (ENVISAGE) Model. World Bank.

49. WHO Commission on Macroeconomics and Health (2001). Macroeconomics and Health: Investing in Health for Economic Development. World Health Organization.

50. World Health Organisation (WHO). (2020a). WHO Characterizes Covid-19 as a Pandemic-11 March. Retrieved June 27, 2020, from https://www.who.int/docs/ default-source/coronaviruse/ transcripts/who-audio-emergencies-coronavirus-press-conference-full-and-final-11 mar2020 pdf? sfvrsn=cb432bb3_2

51. World Health Organization (WHO). (2020b). Archived: WHO Timeline - Covid-19. Retrieved July 4, 2020, from https://www. who.int/news-room/detail/27-042020-who-timeline---covid-19

52. World Health Organization (WHO). (2020c). WHO Coronavirus Disease (Covid-19) Dashboard. Retrieved July 4, 2020, from https://covid19.who.int/

53. World Health Organization (WHO). (2020d). Country \& Technical Guidance - Coronavirus disease (Covid-19). Retrieved July 2, 2020, from https://www. who.int/emergencies/diseases/ novel-coronavirus-2019/technicalguidance-publications 